\title{
Weed Management in Black Gram (Vigna mungo L.) and Residual Effect of Herbicides on Succeeding Mustard (Brasica juncea L.) Crop
}

\author{
Sooraj Chandra Pankaj* and Pradeep Kumar Dewangan
}

Department of Agronomy, Ranchi Agriculture College, Birsa Agricultural University, Kanke, (Ranchi), Jharkhand 834006, India

*Corresponding author

\section{A B S T R A C T}

\section{Keywords}

Blackgram, Mustard, Phyto-toxicity,

Residual effect, Weed management

Article Info

Accepted:

10 September 2017

Available Online:

10 November 2017
Black gram is infested with different categories of weeds. Among broad leaved weeds Parthenium hysterophorus, Phyllanthus niruri, Amaranthus viridis, Celosia argentea, Cleome viscosa, Trianthema portulacastrum; among grassy Echinochloa spp., Setaria glauca, Digera arvensis, Elusine indica, Dectyloctenium aegyptium, Cynodon dactylon and among sedges Cyperus rotundus, Cyperus difformis dominate. Echinochloa colona alone, one of the major weeds in black gram, may reduce the seed yield to the extent of $49-80 \%$. No phytotoxic effects on blackgram in terms of epinasty, hyponasty, necrosis, vein clearing and wilting at $3,5,7$ and 15 days after application of quizalofop-ethyl@37.5 g/ha, fenoxaprop-p-ethyl $100 @ \mathrm{~g} / \mathrm{ha}$ and thus, found completely safe for the crop and also found no residual effect on soil.

\section{Introduction}

Pulses are a source of supplementary protein to daily diets based on cereals and starchy food for a predominantly vegetarian population and for those who cannot afford expensive animal protein. Pulses are therefore often regarded as poor man's meat. They also provide energy, essential minerals, vitamins and several compounds considered beneficial for good health. Their cultivation enriches soil by adding nitrogen and improves the physical, chemical and biological soil properties. The demand of pulses is fast increasing, both in developed and developing countries, where they meet the minimum protein requirements of an increasing population turning to a vegetarian diet. Their productivity can he doubled by improved cultivars and by modern production technologies.

Black gram is one of the important pulse crop grown in India. It being a short duration crop suits well in the cropping system, as it vacates field well in time giving the opportunity to many winter crops like mustard, lentil etc grown in limited and rainfed situation. Black gram is grown in about 3.25 million ha with productivity of $604 \mathrm{~kg} / \mathrm{ha}$ in India (Anonymous, 2015a). Similarly mustard is grown in about 5.8 million ha, with productivity of $1083 \mathrm{~kg} / \mathrm{ha}$ in India 
(Anonymous, 2015b). Black gram (Vigna mungo L. Hepper) also known as urdbean, mash, mungbean, black maple etc. is another important short duration pulse crop grown in many parts of India. Black gram reported to be originated in India. It is a self-pollinated annual crop belonging to leguminaceae family and supplies a major share of protein requirement of vegetarian population of the country. Legumes occupy a special place in human nutrition with protein (24\%), carbohydrates $(59.6 \%)$, fat $(1.5 \%)$, minerals (3.2\%) and it also contains $154 \mathrm{mg}$ calcium, $9.1 \mathrm{mg}$ iron and $38 \mathrm{mg}$ beta-carotene per 100 $\mathrm{g}$ of dal (Gowda and Kaul, 1982).

Among various production factors, weed plays vital role in influencing black gram yield. Weeds compete with the resources like nutrient, moisture and light. High temperature coupled with frequent rains during growing period infests the crop heavily with weeds which adversely affect the productivity of this crop. An initial period of 20-40 days is very critical (Saraswat and Mishra, 1993). The yield loss of black gram due to weeds has been reported to the extent of 27 to $90 \%$ depending upon type and intensity of weed flora (Kumar et al., 2000 and Singh et al., 2010). The yield loss in mustard as a result of weed infestation is also to the tune of $10-58 \%$ (Gill et al., 1989). Black gram is infested with different categories of weeds. Among broad leaved weeds Parthenium hysterophorus, Phyllanthus niruri, Amaranthus viridis, Celosia argentea, Cleome viscosa, Trianthema portulacastrum; among grassy Echinochloa spp., Setaria glauca, Digera arvensis, Elusine indica, Dectyloctenium aegyptium, Cynodon dactylon and among sedges Cyperus rotundus, Cyperus difformis dominate. Echinochloa colona alone, one of the major weeds in black gram, may reduce the seed yield to the extent of $49 \%$ (Rao and Rao, 2003). Mustard in sequence also infested with winter weeds like, Coronopus didymus, Melilotus indica, Vicia sativa, Vicia hirsuta,
Chenopodium album etc among broad leaved weeds. While among grassy Avena fatua, Phalaris minor, dominate. Thus, it is necessary to eliminate weeds from crop at proper time and with suitable methods.

Weeds are controlled by various methods like cultural, manual, mechanical, biological and chemical. Manual and mechanical weeding is laborer intensive and tedious. Many times labours are not available at peak time of requirement for weeding. Even if they are available the escalating cost of laborers further limits its option. The cultural method of weed control like adoption of suitable crop rotation, stale seed bed method, reduced tillage and soil solarization etc is long term planning. The chemical method of weed control is not only cost effective but also is efficient in minimizing weed infestation for longer period provided they are applied judiciously i.e. with suitable herbicide, in dose and time. Season long weed management in black gram may also cover effective weed control for succeeding mustard in winter seasons. There are herbicides which show prolonged persistence in soil resulting in reduced weed infestation in succeeding crops in the system. Contrary to this, sometimes undesirable herbicide in respect to crop its dose, time and method of application may lead to residual hazards in soil and produced, which can be harmful for human and animals (Arora et al., 2013). Pertinent review on "weed management in blackgram and residual effect of herbicides on succeeding mustard crop" has been presented here.

\section{Weed flora of blackgram}

The degree of damage caused by weeds is related to the type, species and density of weeds growing in a crop community, as weeds vary from place to place and season to season. 
Mundra and Maliwal (2012) studying on weed management at Udaipur, Rajasthan reported Echinochloa spp. and Cynodon dactylon among narrow-leaved weeds, Cyperus rotundus and Cyperus difformis among sedges, Digera arvensis and Elusine indica among grasses and Parthenium hysterophorus, Amaranthus viridis, Triantherma portulacstrum etc among broadleaved weeds as major weed flora in blackgram among all weeds. Choudhary et al., (2014) studying on weed management in blackgram at Kanpur reported the major weed species viz., Parthenium hysterophorus, Cyperus rotundus, Digera arvensis and Leptochloa chinensis as major weed flora among of total weed density. Jakhar et al., (2015) found Amaranthus viridis, A. spinosus and Trianthema portulacastrum, Euphorbia hirta, Verbesina encelioides, Digera arvensis, Corchorus acutangulus, Phyllanthus niruri and Physalis minima were dicot weeds found to infest the experimental field. Cyperus rotundus, Dactylactenium aegypticum, Cynodon dactylon, Digitaria sanguinalis and Cenchrus biflorus were found to be the prominent monocot weed species in blackgram crop among of total weed density.

Naidu et al., (2012) reported that the predominant weed flora of the experimental field of blackgram at Naira, Andhra Pradesh were Vicia sativa, Cardiospermum halicacabum L. var. lurid um, Grangea maderaspatana, Chrozophora rottleri, Phyllanthus maderaspatensis and Xanthium strumarium. Das et al., (2014) found that the experimental field of blackgram at Nadia, West Bengal was dominated by natural infestation of broad leaf weed (BLW) like Ageratum conyzoids, Boreria hispida, Commelina banghalensis and grasses like Echinochloa colona, Cynodon dactylon, Paspalum scrobiculatum, Digiteria sanguinalis and sedges like Cyperus rotundus. According to Aggarwal et al.,
(2014) the major weed flora in the experimental fields of blackgram at Ludhiana, Punjab were included Dactyloctenum aegyptiacum (crowfoot grass), Cyperus rotundus (purple nutsedge), Cynodon dactylon (bermuda grass), Commelina benghalensis (benghal dayflower), Eragrostis pilosa (soft love grass), Trianthema portulacastrum (horse purslane) and Digitaria arvensis (wild crab grass). The major weeds were Echinochloa colonum (L.) Link, Echinochloa crusgalli Beav and Panicum repens (L.) among grasses, Cyperus rotundus (L.) and Cyperus difformis (L.) among sedges and Sphaeranthus indicus (L.), Eclipta alba (L.) Hassk and Cleome viscosa (L.) among broad leaved weeds. Eleusine indica, Cynodon dactylon, Bidens pilosa and Mimosa pudica were the dominant weed species under under North Eastern Hill region of India in blackgram (Sahay et al., (1999). Most problematic weeds in blackgram were Echinochloa colona, Digitaria sanguinalis, Trianthema portulacastrum, Amaranthus viridis and Cyperus rotundus in lateritic soils (De and Modak, 1993). The major weeds giving stress to blackgram are Cyperus rotundus, E. colonum, Panicum sp. and Trianthema portulacastrum (Reddy et al., 2000). Rana et al., (2008) reported that Trianthema portulacastrum, Digera arvensis, Echinochloa crusgalli, Parthenium hysterophorus, Phyllanthus niruri and Cynodon dactylon were the most predominating weeds in blackgram. Blackgram was dominated by natural infestation of broad leaved weeds like Grangea maderaspatana, Gnaphalium polycaulon, Nasturtium indicum, Chrozophora rottleri, Cardanthera uliginosa, Xanthium strumarium and grasses like Echinochloa colona, Dinebra retroflexa, Leptochloa chinensis. (Rao et al., 2010). Singh et al., (1991) reported that the major weed species during the monsoon seasons in blackgram were Echinochloa colonum, 
Dactyloctenium aegyptium, Eleusine indica, Digitaria sanguinalis, Celosia argentea, Phyllanthus niruri, Cleome viscosa, Cyperus rotundus and $C$. iria. During the summer seasons E. colonum, D. aegyptium, Physalis minima, Portulaca quadrifida and $C$. rotundus were the major weed species. Tomar (2011) revealed that the dominant grass weed flora in kharif blackgram were Digitaria sanguinalis, Echinochloa colona, Echinochloa crus-galli and Eleusine indica, while among the sedge, weed flora was dominated by Cyperus rotundus. The dominant weed species found in kharif season blackgram crop were Celosia argentia, Cynodon daclylon, Phyllanthus niruri and Cyperus rotundus were found throughout the crop growth period (Nirala, 2012).

\section{Critical period of crop weed competition}

Determination of period of maximum weed competition (critical period of crop weed competition) in the black gram crop is most important in deciding and formulating the weed control programme.

In field studies conducted in blackgram under different agro ecosystems, full season competition lead to $30-80$ per cent reduction due to weed infestation in yield of blackgram (Dhingra et al., 1984). Chaudhry et al., (1989) reported that highest increase in grain yield of 50 and 40-80 per cent was observed in blackgram and green gram respectively when the plots were kept weed free after 4 weeks and up to 6-7 weeks after crop emergence. Sharma et al., (1991) reported the most critical period for crop weed competition was 4-5 weeks after sowing for maize-blackgram intercropping system under rainy season. Singh et al., (1991) reported that grain yields blackgram crop during two seasons increased significantly with the increase in weed-free duration up to 30 DAS. However, a weed-free condition maintained beyond $30 \mathrm{DAS}$ induced no further improvements in grain yields. The period during the first 30 DAS for monsoon planted blackgram was found to be critical for crop weed competition. If weeds are allowed to compete with crops beyond two weeks of sowing there leads to tremendous reduction in yield and weeds during first four to seven weeks may result in about fifty per cent yield loss in blackgram (Singh, 1985). Weed emergence in first four weeks is quite high and the initial four to five weeks are considered to be critical for urd bean (Singh, 1993). Sheoran et al., (2008) reported that unchecked weed competition caused 53.7 per cent green gram seed yield reduction compared to weed free check. Most significant reduction in seed yield occurred when weed free conditions were maintained for the initial 20 days of sowing and unchecked weed infestation up to 40 DAS and thereafter. Thus, the critical period of crop weed competition lies between 20-40 days after sowing in rainy season seeded green gram under rainfed conditions. Rana et al., (2008) reported that the critical period of weed competition was between 30 to 45 DAS during which the crop should be kept free of weeds to prevent the potential loss in blackgram grain yield.

\section{Effect of physical method of weed control}

Singh et al., (2014a) studying weed management in black gram crop at Madhya Pradesh condition found that highest weed control efficiency was with two hand weeding at 20 and 40 days after sowing and was at par with application of pendimethalin $30 \mathrm{EC}+$ imazethapyr 2 EC @ $1.0 \mathrm{~kg}$ a.i/ha as preemergence as compared to application of quizalofop-ethyl $5 \mathrm{EC}$ and fenoxaprop-p-ethyl 9 EC as post-emergence. Shaikh et al., (2002) conducted a field experiment on weed management in blackgram and reported that highest mean weed-control efficiency (56\%) at harvest was observed under two hand- 
weeding and hoeing followed by preemergence of oxyfluorfen $0.10 \mathrm{~kg} / \mathrm{ha}$ compare to other treatments. Tamang et al., (2015) observed that hand weeding at 20 and 40 DAS significantly reduced weed density, weed biomass and improved the grain yield of green gram, gave less benefit: cost ratio owing to higher cost of farm labour as compare to different herbicides. Buttar and Grover (2006) found that the lowest dry matter of weeds was recorded in hand weeding at 5 weeks after sowing and pendimethalin@ $0.750 \mathrm{~kg} / \mathrm{ha}$ as compared to unweeded control. Chhodavadia et al., (2012) found that the lowest dry weight of weed was recorded under two hand weeding and two interculturing at 20 DAS \& 40 DAS and highest dry weight of weeds that pendimethalin @ $0.900 \mathrm{~kg} / \mathrm{ha}$. The lowest weed index (2.68 percent) and highest weed control efficiency (55.69 percent) was observed when two hand weeding and two interculturing at 20 DAS \& 40 DAS followed by oxyfluorfen @ $0.180 \mathrm{~kg} / \mathrm{ha}+1$ hand weeding at 30 DAS (4.68 percent, 51.58 percent respectively). Net income was also obtained significantly maximum of 13916/ha under hand weeding followed by clethodium @ 60 g/ha treatment with. 9232/ha at Kanpur. Suryakant et al., (1989) revealed that hand weeding twice at 15 and 25 days after sowing proved to be most beneficial in controlling weeds followed by hand weeding once at 25 DAS and gave 183.49 per cent and 127.56 per cent increase in yield over control, respectively. Singh et al., (1998) reported that highest mean plant height of blackgram was recorded under two hand weeding and hoeing at three and five weeks after sowing which was on par with all other weed control treatments and significantly superior to unweeded check. Ramamoorthy and Lakshmanachary (1999) found lesser weed competition index, higher weed control efficiency and weed control index in manually weeded plots in blackgram.
Kathiresan (2002) reported that twice hand weeding recorded highest grain yields which were 58.39 and 61.55 per cent higher than the unweeded control in first and second year blackgram, respectively under rice-blackgram sequence. Chaudhry et al., (2014) reported that hand hoeing at 30 and 60 DAS gave higher weed control i.e. 95.77 and 98.12 per cent of broad and narrow leaved weeds over control, respectively and produced lowest weed dry matter $\left(15.46 \mathrm{~g} / \mathrm{m}^{2}\right)$. Maximum reduction in weed density, weed biomass and highest weed control efficiency, yield and harvest index were obtained in plots where hand weeding was done twice at 15 and 30 DAS and it was closely followed by the treatment quizalofop ethyl @ 50 g/ha with hand weeding at 30 DAS which also recorded highest B: C ratio, (Kundu et al., 2011).

\section{Effect of chemical method of weed control}

When labour is scarce and expensive, use of herbicides holds good promise from the point of less cost and efficient weed control from the sowing itself. Most weeds emerge before or along with crop and thereby necessitate the use of pre plant incorporation and preemergence herbicides. Chemical weed control in black gram has been found effective and economical

\section{Quizalofop-p-ethyl}

Mundra and Maliwal (2012) conducted a field experiment on sandy clay loam soil in blackgram crop at Udaipur, Rajasthan and reported lowest narrow-leaved weed density and weed dry weight at 30 DAS with the application of quizalofop-ethyl @ 50 g/ha than application of quizalofop-ethyl @ 37.5 $\mathrm{g} / \mathrm{ha}$, pendimethalin @ $750 \mathrm{~g} / \mathrm{ha}$ and hand weeding twice. Mahakavi et al., (2014) reported that among the various concentration of herbicide quizalofop-p-ethyl @ 0.5, 1, 1.5 and $2 \%$ treatment used in the experiment 
$0.5 \%$ is the safest for weed control in black gram (Vigna mungo L.) as it had least adverse effect on growth, yield and enzymes activities of crop at Chidambaram, Tamil Nadu, India. Tomar (2011) reported that post emergence application of quizalofop-p-tefuryl 4.41 per cent EC @ $1500 \mathrm{ml} / \mathrm{ha}$ at 15 DAS has given significant weed control of grassy weeds and increased the seed yield of blackgram. Application of quizalofop-p-tefuryl 4.41 per cent EC @ $1000 \mathrm{ml} / \mathrm{ha}$ and fenoxaprop-pethyl 9.3 per cent EC @ $750 \mathrm{ml} / \mathrm{ha}$ were statistically at par in reducing weed density at 15 and 30 days after application. Rao (2011) reported that Post emergence application quizalofop ethyl at $50 \mathrm{~g} / \mathrm{ha}$ recorded the highest seed yield $(1877 \mathrm{~kg} / \mathrm{ha})$, net monetary returns ( 35,625/ha) and $\mathrm{B}: \mathrm{C}$ ratio of 3.15 and was on par with hand weeding at 15 and 30 DAS, which recorded the highest seed yield of $1928 \mathrm{~kg} / \mathrm{ha}$. Mundra and Maliwal (2012) reported that quizalofop-p-ethyl 50 $\mathrm{g} / \mathrm{ha}$ recorded the lowest narrow-leaved weed density and dry weight at 30 DAS and at harvest during. The weed control efficiency of quizalofop-p-ethyl $50 \mathrm{~g} / \mathrm{ha}$ was 81.3 per cent than the highest (85.6 per cent) under two hand weedings against grassy weeds at harvest. Number of branches and pods/plant, seeds/pod and grain and stover yields of blackgram were also superior in plots treated with quizalofop-p-ethyl $50 \mathrm{~g} /$ ha or two HW.

\section{Fenoxaprop-p-ethyl}

A field experiment carried out at Namakkal, Tamil Nadu by Deivasigamani (2016) found that application of fenoxaprop-p-ethyl @ 875 $\mathrm{ml} / \mathrm{ha}$ and similar to $750 \mathrm{ml} / \mathrm{ha}$ applied at 2-4 leaf weed stage recorded the least weed counts of individual species viz., Echinochloa $s p$ Digitaria $s p$ and Dactyloctenium $s p$, weed dry matter production and weed control index favoring to higher pod yield of (1870.50 and 1455.00 kg/ha). Fenoxaprop-p-ethyl @625 $\mathrm{ml} / \mathrm{ha}$ and quizalofop-p-ethyl @750 ml/ha was next in order. Rao (2008) reported that post-emergence application of fenoxaprop-pethyl, clodinafop-propargyl and cyhalofopbutyl significantly reduced Echinochloa colona growth and increased blackgram yield by 27 to 42 per cent over weedy check without any crop injury. Herbicide application at 21 and 28 days after sowing (DAS) resulted in significantly higher reduction in Echinochloa colona density at 20 and 40 days after treatment (DAT) and total weed dry weight compared to its application at 14 DAS in relay blackgram. Maximum seed yield of $401.0 \mathrm{~kg} / \mathrm{ha}$ was obtained from hand hoeing followed by post emergence herbicide fenoxaprop-p-ethyl 75 EW applied @ 1.2 lit/ha with $353.2 \mathrm{~kg} / \mathrm{ha}$ seed yield against $212.2 \mathrm{~kg} / \mathrm{ha}$ from weedy check treatment, (Ansar et al., 2010). Application of quizalofop-p-ethyl at 20 DAS and fenoxaprop-p-ethyl at 20 DAS in combination with hand weeding and Interculture at 30 DAS was found to be relatively more effective in controlling weeds and giving better crop growth and yield than their sole application, (Chhodavadia, 2014).

\section{Imazethapyr}

Chin and Pandey (1991) from IARI reported that imazethapyr at $0.075 \mathrm{~kg} / \mathrm{ha}$ lowered total weed population significantly and it controlled Trianthema portulacastrum better than fluchloralin at $1.0 \mathrm{~kg} / \mathrm{ha}$. Imazethapyr at $1.0 \mathrm{~kg} / \mathrm{ha}$ and hand weeding at 20 DAS were statistically comparable, which is attributed to better spread of blackgram crop canopy there by restricting the light interception by weeds (Velayudham, 2007). Veeraputhiran and Chinnusamy (2008) reported that imazethapyr as post emergence application at $0.09 \mathrm{~kg} / \mathrm{ha}$ was superior over 0.06 and $0.075 \mathrm{~kg} / \mathrm{ha}$ and the herbicide applied at 21 and 28 DAS were at par followed by 14 DAS. Nandan et al., (2011) reported that imazethapyr at $250 \mathrm{ml} / \mathrm{ha}$ post emergence treatment at 15-20 DAS has 
given similar seed yield as of weed free check succeeded by pendimethalin@1 kg/ha with $1 \mathrm{HW}$ at 30 DAS. Post emergence application of imazethapyr @ $0.2 \mathrm{~kg} / \mathrm{ha}$ was significant on reducing weed density and dry matter but however toxicity symptom was seen @ 0.150 and $0.2 \mathrm{~kg} / \mathrm{ha}$ but the plants recovered early from the lower dosage. Economically preemergent application of pendimethalin @ 1.0 $\mathrm{kg} / \mathrm{ha}$ was superior (Naidu et al., 2012). Highest number of pods/plant, number of seed/plant, number of seed/pod, seed yield, stover yield and harvest index were obtained under hand weeding twice (20 and 40 DAS), followed by imazethapyr @ $25 \mathrm{~g} / \mathrm{ha}$ PE and minimum was obtained under unweeded check. The lowest density and dry matter production of weeds, weed intensity, weed growth rate, relative weed density and weed control efficiency were recorded under hand weeding twice (20 and 40 DAS) followed by imazethapyr @ 25 g/ha PE as reported by Nirala et al., (2012).

\section{Pendimethalin}

Jain and Jain (1987) noticed that pendimethalin at $1.0 \mathrm{~kg} / \mathrm{ha}$ in general imposed a knock down effect on some weeds and offered a weed free media at initial stages of crop growth which lead to increase in yield of 157 per cent over control. Singh and Singh (1990) reported that pendimethalin at 0.75 $\mathrm{kg} / \mathrm{ha}$ gave higher seed yields $(680 \mathrm{~kg})$ which was on par with two manual weedings at 20 and 35 DAS. Reddy et al., (2000) reported that application of pendimethalin, metolachlor, alachlor each at $1.5 \mathrm{~kg} / \mathrm{ha}$ to blackgram was effective in controlling weeds and resulted in similar yield as that of hand weeded crop. Venkateswarulu et al., (1988) conducted experiment in Bapatla (A.P) and found that pre-emergence application of pendimethalin at $1.0 \mathrm{~kg} / \mathrm{ha}$ recorded highest grain yield of $979 \mathrm{~kg} / \mathrm{ha}$ and minimum grain yield was recorded with unweeded check of
$405 \mathrm{~kg} / \mathrm{ha}$. Rathi et al., (2004) reported that low dose of pendimethalin $(0.5 \mathrm{~kg} / \mathrm{ha})$ followed by one hand weeding done at 60 days after sowing demonstrated intended weed control (67.80 per cent WCE), enhanced grain yield (379 kg/ha or 119.49 per cent) and fetched net monetary returns ( 3611/ha) due to weed control in blackgram (Vigna mungo L.) grown under rainfed eco-system of Central Uttar Pradesh. Rao et al., (2010) reported that pre emergence sand mix application of pendimethalin $1.0 \mathrm{~kg} / \mathrm{ha}$ followed by imazethapyr $50 \mathrm{~g} / \mathrm{ha}$ at 20 days after sowing (DAS) significantly reduced weed growth and recorded the highest seed yield $(1113 \mathrm{~kg} / \mathrm{ha})$. Uncontrolled weed growth caused 61 per cent reduction in seed yield of blackgram. Sequential applications of herbicides are better than single herbicide application (Rao 2011).

\section{Oxyfluorfen}

Shrivas et al., 2013) revealed that the lowest weed density and biomass were recorded with one hand weeding at 20 days after sowing (DAS) followed by application of oxyfluorfen $100 \mathrm{ml} / \mathrm{ha}$ as pre-emergence at (2 DAS). Among the herbicidal treatments i.e. imazethapyr with $0.2 \%$ surfactant it was observed that $75,125,200$ and oxyfluorfen $100 \mathrm{ml} / \mathrm{ha}$ at $2 \mathrm{DAS}$, the latter was most effective in reducing the weed population and dry matter accumulation and gave highest net return ( 37575/ha) and the benefit-cost ratio (2.38) on sandy loam soil at Allahabad. Yadav et al., (1997) reported that oxyfluorfen at $0.20 \mathrm{~kg} / \mathrm{ha}$ with one hand weeding at 25 DAS was most effective in controlling weed population and was followed by fluchloralin at $1.25 \mathrm{~kg} / \mathrm{ha}$ with one hand weeding at 25 DAS. Shaikh et al., (2002) reported that application of oxyfluorfen @ $0.10 \mathrm{~kg} / \mathrm{ha}$ recorded highest seed yield $(6.79 \mathrm{q} / \mathrm{ha})$ in blackgram similar to application of fluchloralin @ $0.9 \mathrm{~kg} / \mathrm{ha}$, pendimethalin @ 
$0.75 \mathrm{~kg} / \mathrm{ha}$, metolachlor @ $1.0 \mathrm{~kg} / \mathrm{ha}$, two hoeing at 3 and 5 week after sowing, two hand weeding at 3 and 5 week after sowing and was significantly higher to weedy check $(4.71 \mathrm{q} / \mathrm{ha})$ at Parbhani.

\section{Integrated approach for weed management}

Continuous use of herbicides may cause environmental pollution and plants may lead to development of resistance against these chemicals. Therefore, it is necessary to utilize more than one methods of weed control for sustaining the productivity and profitability of crops and cropping system. From different experiment conducted all over country, it can be interpreted that combined use of chemical and one hand weeding yielded better than any single component.

Higher grain yield under integrated weed control treatments (herbicide + hand weeding + interculturing) may be attributed mainly to the better control of weeds during different stages, manual removal of weeds emerging, weeding and interculturing at subsequent stages, resulting in reduced crop-weed competition and thereby providing better yield attributes, similarly result found in blackgram crop by Vivek et al., (2008). Singh (2011) revealed that pendimethalin 0.75 $\mathrm{kg} / \mathrm{ha}$, pendimethalin $0.45 \mathrm{~kg} / \mathrm{ha}$ followed by hand weeding 25 DAS, two hand weeding at 25 and 40 DAS and weedy check recorded weed dry matter of $4.87,3.45,3.40$ and 23.6 $\mathrm{q} / \mathrm{ha}$ and grain yield of $11.47,11.75,11.95$ and $7.02 \mathrm{q} / \mathrm{ha}$, respectively in summer season likewise in kharif season, the respective treatments had weed dry matter of 4.16, 4.26, 2.90 and 20.9 q/ha and grain yield of 10.43, $10.76,11.76$ and $6.86 \mathrm{q} / \mathrm{ha}$, respectively. Choudhary et al., (2012) reported that preemergence application of pendimethalin @ 1.5 lit/ha with one hand weeding on 25 DAS was on par with 2 hand weedings at 15 and 25 DAS in respect of seed yield, net returns and
B:C ratio. Chhodavadia et al., (2012) found that among the treatment, application of two hand weeding and two interculturing at $20 \&$ 40 DAS produced highest grain $(977 \mathrm{~kg} / \mathrm{ha})$ and stover yield (1376 kg/ha), respectively, and closely followed by oxyfluorfen @ 0.180 $\mathrm{kg} / \mathrm{ha}+1 \mathrm{HW}$ at $30 \mathrm{DAS}$ with seed and stover yield of $957 \mathrm{~kg} / \mathrm{ha}$ and $1365 \mathrm{~kg} / \mathrm{ha}$. Ram et al., (2013) found that highest net returns were recorded in imazethapyr @ $75 \mathrm{~g} / \mathrm{ha}$ applied at 25 DAS, which was statistically on par with imazethapyr @75 g/ha applied at 15 DAS and imazethapyr @100 g/ha applied at 15 or 25 DAS and pendimethalin $45 \mathrm{~g} / \mathrm{ha}+$ hand weeding (40 DAS) but significantly higher than imazethapyr @ $50 \mathrm{~g} / \mathrm{ha}$ applied at 15 or 25 DAS, two hand weeding and unweeded check at Ludhiana. Khot et al., (2013) revealed that application of pendimethalin (1 $\mathrm{kg} / \mathrm{ha}$ pre-emergence) $+1 \mathrm{HW}+\mathrm{IC}$ at 40 DAS was found most effective in reducing weed population. It was closely followed by oxyfluorfen $0.18 \mathrm{~kg} / \mathrm{ha}$ pre-emergence +1 $\mathrm{HW}+\mathrm{IC}$ at 40 DAS. Pendimethalin $1 \mathrm{~kg} / \mathrm{ha}$ pre-emergence $+1 \mathrm{HW}+\mathrm{IC}$ at $40 \mathrm{DAS}$ and oxyfluorfen $0.18 \mathrm{~kg} / \mathrm{ha}$ pre-emergence +1 $\mathrm{HW}+\mathrm{IC}$ at 40 DAS were found equally effective. Two hand weedings at 20 and 40 DAS was found statistically at par with chemical treatments.

\section{Effect of weed management practices on blackgram crop}

\section{Growth}

Veeraputhiran and Chinnusamy, (2008) reported that no significant difference in plant height was found due to different time of application of imazethapyr while application at 21 and 28 DAS registered significantly higher LAI and dry matter accumulation than applied at 14 DAS. Choudhary et al., (2012) reported that pre-emergence application of pendimethalin@1.5 lit/ha, fluchloralin@1.5 lit/ha, pendimethalin @ 1.5 lit/ha + hand 
weeding at $25 \mathrm{DAS}$, fluchloralin @ 1.5 lit/ha + hand weeding at 25 DAS recorded higher number of nodule and nodule dry weight of black gram similar to hand weeding twice. Higher number of nodule and dry weight also has been reported by Aggarwal et al., (2014) that integrated application of imazethapyr @ $75 \mathrm{~g} / \mathrm{ha}$ at 15 DAS and two hand-weedings at 20 and 40 DAS recorded higher number of nodule and nodule dry weight of blackgram compared to application of imazethapyr @ 50 and $100 \mathrm{~g} / \mathrm{ha}$ at $15 \mathrm{DAS}$ as well as application of imazethapyr @ 50,75 and 100 g/ha at 20 DAS. According to Goud et al., (2013) found that among the herbicides and dosage, a maximum reduction of $75.49 \%$ and $67.65 \%$ in number of nodules per plant was obtained with imazethapyr and quizalofop-ehtyl @ 100 $\mathrm{g} / \mathrm{ha}$ at 25 DAS, respectively, compared to hand weeding at 25 and 35 DAS at Akola. Gowada et al., (1994) reported that preemergent application of pendimethalin @ 1 $\mathrm{kg} / \mathrm{ha}$ completely inhibit germination of finger millet. However, in red gram the germination as well as seedling establishment were not affected. Yadav and Singh (2005) found that application of pendimethalin @ $1 \mathrm{~kg} / \mathrm{ha}$ as pre-emergence, maximum reduction in germination percentage was also observed in K-851 (52.4\%) followed by T-44 (51.4\%), Pant Mung-2 (46.2\%) and NDM-1 (45.1\%) at Faizabad.

\section{Yield attributes}

Choudhary et al., (2012) reported that, integrated application of pendimethalin@1.5 lit/ha + hand weeding at 25 DAS recorded higher pods/plant (38.1) compared to fluchloralin @ 1.5 lit/ha (34.1) and was similar to pendimethalin@1.5 lit/ha (36.0) in blackgram crop. Mahakavi et al., (2014) reported that higher concentration of quizalofop-p-ethyl i.e. $1,1.5$ and $2 \%$ decreased number of pods/plant, seeds/plant and weight of 100 seeds whereas lower concentration $0.5 \%$ stimulated the yield attributing character of blackgram at Chidambaram, India. Mundra and Maliwal (2012) also observed that reduced number of branches/plant (4.23), pods/plant (31.67) and seed/pod (6.47) were recorded due to application of quizalofop-ethyl $50 \mathrm{~g} / \mathrm{ha}$ compared to farmers practice recording 4.99, 37.48 and 6.93 , respectively on sandy clay loam soil in blackgram crop. The increase in growth and yield attributes under these treatments might be attributed due to the reduction in weed competitiveness with the crop which ultimately favoured better environment for growth and development of crop. Singh et al., (2010) reported that highest number of pods per plant and 1000grain weight was obtained in haloxyfop 10 EC @ $100 \mathrm{~g} / \mathrm{ha}$ which was found statistically equal with the yield of weed free plot during both the years, 2007 and 2008 among all the chemical treatments like haloxyfop (10 EC) with three doses at 75 and $125 \mathrm{~g} / \mathrm{ha}$, quizalofop (5 EC) $50 \mathrm{~g} / \mathrm{ha}$, fenoxaprop (9.3 EC) $100 \mathrm{~g} / \mathrm{ha}$ and two hand weeding (at 30 and 45 DAS). Chhodavadia et al., (2012) found that branches/plant, number of pods/plant, length of pod $(\mathrm{cm})$, number of grain/pod, grain weight/plant (g) and test weight (g) of green gram increased significantly created due to application of two hand weeding and two interculturing at 20 DAS \& 40 DAS and at par with oxyfluorfen @ $0.180 \mathrm{~kg} / \mathrm{ha}+1$ hand weeding at $30 \mathrm{DAS}$ supplemented with post-emergence herbicide as compare to weedy check.

\section{Yield}

Mundra and Maliwal (2012) observed that per cent increase in seed yield of blackgram due to two hand weeding at 20 and 30 DAS, quizalofop-p-ethyl $50 \mathrm{~g} / \mathrm{ha}$, pendimethalin $750 \mathrm{~g} / \mathrm{ha}$ and quizalofop-ethyl $37.5 \mathrm{~g} / \mathrm{ha}$ to the extent of 226.1, 188.6, 141.7 and 126.5, respectively compared to weedy check in 
sandy loam soil of Rajasthan. Application of imazethapyr @ $70 \mathrm{~g} / \mathrm{ha}$ as post emergence recorded highest black gram seed yield (643 $\mathrm{kg} / \mathrm{ha}$ ) followed by pendimethalin @ 1.0 $\mathrm{kg} / \mathrm{ha}$ as PE (537 kg/ha) and imazethapyr @ $50 \mathrm{~g} / \mathrm{ha}(527 \mathrm{~kg} / \mathrm{ha})$ as compare to weedy check (390 kg/ha) at Gwalior Anonymous, (2013). Nandan et al., (2011) reported that highest seed yield ( $0.74 \mathrm{t} / \mathrm{ha})$ of blackgram with application of imazethapyr 10\% SL @ $250 \mathrm{ml} / \mathrm{ha}$ at $15-20$ days after sowing and was followed by hand weeding twice at 20 and 40 days after sowing (0.73 t/ha) at Shiwalik, Jammu and Kashmir. The summarised experimental data showed that there was yield reduction of $34.3 \%$ to $39.8 \%$ due to weed infestation. On country basis such losses in crop yields have been estimated at $15-30 \%$ in wheat, $30-35 \%$ in rice and $18-85 \%$ each in maize, sorghum, pulses and oilseeds (Mukhopadhyay, 1992).

\section{Economics}

Nandan et al., (2011) reported that amongst weed management treatments in blackgram with the application of imazethapyr 10\% SL @ $250 \mathrm{ml} / \mathrm{ha}$ at $15-20 \mathrm{DAS}$ recorded highest net return ( $20,215 /$ ha) and was followed by hand weeding twice at 20 and 40 DAS (' $20,145 / \mathrm{ha}$ ) as compare to weedy check ( $11,727 /$ ha) at Shiwalik, Jammu and Kashmir. Aggarwal et al., (2014) reported highest gross and net return in blackgram with the application of imazethapyr @ $100 \mathrm{~g} / \mathrm{ha}$ at 15 DAS and two hand-weedings 20 and 40 DAS than all other treatments like imazethapyr @ 50 and $75 \mathrm{~g} / \mathrm{ha}$ at 15 DAS, imazethapyr @ 50 and $75 \mathrm{~g} / \mathrm{ha}$ at 20 DAS and weedy check at Punjab condition. According to Shaikh et al., (2002) application of oxyfluorfen @ 0.10 $\mathrm{kg} / \mathrm{ha}$ being at par with application of fluchloralin@0.9 kg/ha, pendimethalin @ $0.75 \mathrm{~kg} / \mathrm{ha}$, metolachlor @ $1.0 \mathrm{~kg} / \mathrm{ha}$, two hoeing at 3 and 5 week after sowing and two hand weeding at 3 and 5 week after sowing recorded highest relative monetary return ( 8,890/ha) and benefit: cost ratio (3.10) and was significantly higher compare to weedy check in blackgram crop at Prabhani. Meena et al., (2011) reported that application of imazethapyr XL 10\% SL at $100 \mathrm{~g} / \mathrm{ha}$ recorded significantly higher net return ( $14,237 / \mathrm{ha}$ ) and $\mathrm{B}$ : $\mathrm{C}$ ratio (1.68) followed by imazethapyr XL $10 \%$ at $150 \mathrm{~g} / \mathrm{ha}$ over weedy check and imazethapyr XL $10 \%$ at $50 \mathrm{~g} / \mathrm{ha}$. Chhodavadia et al., (2012) found that the highest net monetary returns of '18354/ha was obtained with two hand weeding and two interculturing at 20 DAS and 40 DAS which was at par with oxyfluorfen @ $0.180 \mathrm{~kg} / \mathrm{ha}+1$ hand weeding at 30 DAS ( 18040/ha). The highest benefit: cost ratio of 2.41 was obtained with two hand weeding and two interculturing at $20 \quad \& \quad 40$ DAS and oxyfluorfen@0.180 kg/ha+ 1 hand weeding at 30 DAS closely followed by pendimethalin @ $0.900 \mathrm{~kg} / \mathrm{ha}+1$ hand weeding + interculturing at 30 DAS and one hand weeding and one interculturing at 30 DAS which may be due to lower cost of treatments than other. De et al., (1995) reported that yield and yield attributes were best in integrated treatments but the treatments were costly. Net profit was highest in hand weeding twice and alachlor at $0.5-1.0 \mathrm{~kg} / \mathrm{ha}$ in blackgram crop.

\section{Quality}

Chhodavadia et al., (2012) found that two hand weeding and two interculturing at 20 \& 40 DAS significantly increased protein content (22.15 percent) and followed by oxyfluorfen@0.180 kg/ha+ 1 hand weeding at 30 DAS (21.87 percent) as compare to weedy check plot in green gram crop at Junagadh, Gujarat. Ramamoorthy and Lakshmanacharya (1997) conducted an experiment to study the effect of different herbicides on the biochemical changes in blackgram at Pondicherry and reported that 
pre-emergence application of pendimethalin (a) $1.0 \mathrm{~kg} / \mathrm{ha}$ increased crude protein of blackgram.

\section{Effect of weed management on microbial studies}

Das et al., (2014) reported that application of herbicides like pendimethalin $1.5 \mathrm{l} / \mathrm{ha}$ and fluchloralin $1.5 \mathrm{l} / \mathrm{ha}$ applied alone and integrated with hand weeding (Pendimethalin @ 1.5 lit/ha + hand weeding at 25 DAS and Fluchloralin@1.5 lit/ha + hand weeding at 25 DAS) in blackgram the population of total bacteria, actinomycetes and fungi increased from 24.57 to $68.64,21.32$ to 63.98 and 19.47 to $57.10 \%$ as compare to weedy check at Mohanpur. Adhikari et al., (2014) showed that the herbicide treatments i.e. pendimethalin 30 EC @ $3300 \mathrm{ml} / \mathrm{ha}$, oxyfluorfen 23.5 EC @ $850 \mathrm{ml} / \mathrm{ha}$, propaquizafop 10 EC @ 750 ml/ha significantly inhibited the development of microbial populations in the soil, and the degree of inhibition varied with the types of herbicide. Increasing trend of inhibition on growth of microbial populations was observed from the initial effect until 15 DAA. No inhibition was observed at 15 DAA to harvest.

The study suggests that the herbicide application to soil cause transient impacts on microbial population growth, when applied at recommended field application rate. Arora and Dubey (2014) revealed that total population of bacteria, actinomycetes and fungi in soil reduced considerably up to 15 days after application of both the herbicides as compared to control. Pendimethalin @ 2.0 $\mathrm{kg} / \mathrm{ha}$ and chlorimuron-p-ethyl @ 18 g/ha showed more suppressive effect on microbial count as compared to their lower doses. However, the microbial population was restored to the level present in the control after 30 days of application and at harvest.

\section{Effect of weed management on nutrient removal}

Research has established that the weed-crop competition for nutrient occur along with other element of completion. Weeds usually uptake mineral nutrient faster than many of our crop part and accumulate them in their tissues in relatively larger amount. Species of Amaranthus for example after accumulate over 3\% N in their dry matter Digitaria spp. on the other hand, is a phosphorus accumulator with $\mathrm{P}_{2} \mathrm{O}_{5}$ content over $3.36 \%$. Chenopodium spp. are likewise potassium lover, with over $4.0 \% \mathrm{~K}_{2} \mathrm{O}$ in dry matter (Gupta, 2013). Choudhary et al., (2012) reported that weedy check plot recorded highest removal of nutrients $(5.9,2.8$ and 7.1 $\mathrm{kg} \mathrm{NPK/ha)} \mathrm{in} \mathrm{black} \mathrm{gram} \mathrm{over} \mathrm{other} \mathrm{weed}$ management practices like fluchloralin @ 1.5 lit/ha $(5.4,2.5$ and $6.3 \mathrm{~kg} / \mathrm{ha})$, pendimethalin @ $1.5 \mathrm{lit} / \mathrm{ha}+$ hand weeding at 25 days after sowing (4.6 2.2 and $5.1 \mathrm{~kg} / \mathrm{ha})$ and fluchloralin @ 1.5 lit/ha + hand weeding at 25 days after sowing $(4.9,2.2$ and $5.5 \mathrm{~kg} / \mathrm{ha})$. Chhodavadia et al., (2012) found that there was vigorous growth of weed in unweeded check treatments which resulted higher uptake of $\mathrm{N}, \mathrm{P}_{2} \mathrm{O}_{5}$ and $\mathrm{K}_{2} \mathrm{O}$ respectively. While two hand weeding and two interculturing at $20 \&$ 40 DAS recorded the least loss of nutrients by weeds followed by the oxyfluorfen @ 0.180 $\mathrm{kg} / \mathrm{ha}$. It can be explained in the light of the facts that these treatments controlled the weeds effectively, might have made more nutrients available to crop and consequently encouraged higher concentration of nutrients and more yield and there by higher uptake of nutrients by the crop. Samant and Mishra (2014) studied that post-emergence application of quizalofop ethyl @ $1.0 \mathrm{~kg} / \mathrm{ha}$ at 15 DAS with one hand weeding at 25 DAS was minimized nitrogen, phosphorus and potash removal by weeds to a tune of 91.2, 84.1 and $89.7 \%$, respectively over that of 
weedy check, resulting in better nutrient uptake by the crop.

\section{Effect of weed management on succeeding crop}

Duration of persistence is very important from weed control point of view. A herbicide should persist during current crop season but carryover effect to next cropping season is not desirable. Finding the duration of herbicide persistence at applied rate will be helpful for determining the toxicity of herbicide to sensitive crop. Irrespective of any dose no residues were detected in cropped soil as well as plant samples at harvest. Mundra and Maliwal (2012) observed that post-emergence application of quizalofop-ethyl 5 EC @ 37.5, $50 \mathrm{~g} / \mathrm{ha}$ and pre-emergence application of pendimethalin $30 \mathrm{EC}$ @ $750 \mathrm{~g} / \mathrm{ha}$ in blackgram did not show phytotoxic effect on succeeding crops, viz. wheat, gram and mustard on sandy clay loam soil at Rajasthan.

Anonymous (2013) reported from Hissar that all the herbicide treatments except imazethapyr @ 70 g/ha and its ready mix combination with imazamox applied in blackgram showed only 5\% toxicity upto 15 DAS on mustard crop which mitigated within one month after planting. Soltani et al., (2015) reported that pendimethalin applied as pre plant incorporation at twice the manufacturer's recommended rate (2160 $\mathrm{g} / \mathrm{ha}$ ) in dry bean in the spring season caused $4 \%$ reduction in yield of winter wheat at harvest time. In other studies, pendimethalin applied at $2240 \mathrm{~g} / \mathrm{ha}$ to lentils in the spring reduced winter wheat grain yield 11 to $17 \%$ at the harvest time in the following year Hanson and Thill (2001).

\section{Phytotoxic effect of herbicides on crop plant}

Naidu et al., (2012) reported that post emergence application of imazethapyr @150 g/ha caused crop injury to blackgram to the extent of 40 per cent resulting in moderate stunting growth of seedling and discolorations of developing leaves with partial loss of crop stand grown in rice-fallow-blackgram at Andhra Pradesh. Mundra and Maliwal (2012) recorded no phytotoxic effects on blackgram in terms of epinasty, hyponasty, necrosis, vein clearing and wilting at 3, 5, 7 and 15 days after application of quizalofop-ethyl @ 37.5 $\mathrm{g} / \mathrm{ha}$ and thus, found completely safe for the crop at Rajasthan. Tomar (2011) from Haryana studied on phytotoxic effect of quizalofop-p-ethyl 4.41\% EC @ 750, 1000 and $1500 \mathrm{ml} / \mathrm{ha}$ and pendimethalin 30 EC @ $2500 \mathrm{ml} / \mathrm{ha}$ as pre-emergence application has not exhibited phytotoxic symptoms on blackgram crop from the time of application till the date of harvest and found safe for the crop. Soltani et al., (2008) reported that crop injury generally increased as the dose of imazethapyr was increased. Imazethapyrapplied @ 300 g/ha as pre-emergence caused up to $62 \%$ visible injury and reduced plant height as much as $32 \%$, shoot dry weight $48 \%$, root dry weight $20 \%$ and yield $77 \%$ as compare to application of imazethapyr @ 50 $\mathrm{g} / \mathrm{ha}$ as pre-emergence. Chopra and Chopra (2005) reported that the succeeding crops of mung bean, cowpeas and forage sorghum did not show any residual activity of fenoxaprop @ $100 \mathrm{~g} / \mathrm{ha}$ applied in wheat crop.

Deivasigamani (2016) reported that no phytotoxicity was observed in the treatments including two times the recommended dose of whip super (fenoxaprop-p-ethyl $875 \mathrm{ml} / \mathrm{ha}$ ) and whip super (Fenoxaprop-p-ethyl 1750 $\mathrm{ml} / \mathrm{ha}$ ) in respect of leaf chlorosis, tip burning, leaf necrosis, leaf epinasty, hyponasty, vein clearing, wilting and resetting.

\section{Herbicide residue in plant and soil}

Cumming et al., (2002) studying the residual concentration of pendimethalin in ferresol, kurosol, sodosol and vertosol soil observed 7 
days after its application the concentration were $41 \%, 52 \%, 46 \%$ and $40 \%$, respectively. While after 365 days, concentrations as a percentage of applied concentration had declined to $4 \%, 3 \%, 2 \%$ and $10 \%$, respectively. Mukhopadhyay et al., (2012) reported that initial concentrations of quizalofop-P-tefuryl residues in soil and plant samples were found to ranges $0.95-2.3$ and $0.41-1.41 \mathrm{mg} / \mathrm{kg}$, respectively. It was found from the results that the half-life value was 4.1-4.14 days and 0.47-0.64 days for soil and plant, respectively. They observed that residues were below the detectable limit in all the harvest samples (soil, plant and seed) irrespective of treatments and found completely safe for the blackgram crop at Mohanpur. Sondhia et al., (2015) reported that imazethapyr was applied at $100 \mathrm{~g} / \mathrm{ha}$, as a post emergence herbicide to control weeds in soybean fields. Residues of imazethapyr were found in the range from 0.006 to $0.018 \mu \mathrm{g} / \mathrm{g}$ in the soybean grains samples in all five locations. However in the soil, residues were found to be below $0.0010 \mu \mathrm{g} / \mathrm{g}$ in four locations, and $0.0015 \mu \mathrm{g} / \mathrm{g}$ in one location. Less residues were found in soils as compared to plant samples. Based on this study a preharvest interval of 90-102 days is suggested for soybean crops after imazethapyr application. This indicates the judicious use of imazethapyr by farmers in soybean fields. Saha et al., (2015) reported that limit of quantification (LOQs) was $5.0 \mu \mathrm{g} / \mathrm{kg}$ for pendimethalin, imazethapyr and quizalofop-pethyl and $10.0 \mu \mathrm{g} / \mathrm{kg}$ for oxyfluorfen. The expanded uncertainties were $<11 \%$ for determination of these herbicides in peanut, the residues were below the detection level. In soybean, Paneerselvam and Solaimalai (1998) have reported no appreciable amount of residue of pendimethalin in soil after harvest to affect the succeeding crops grown in the soybean based crop rotation. Arora and Tomar (2008) suggest that pendimethalin persisted in soil under different crops (gram, lentil, linseed, safflower, rajma, fenugreek, fennel and coriander) up to 75 days after application and beyond that no residues were left in soil at Gwalior. Arora and Dubey (2014) observed that pre-emergence application of pendimethalin @ 2.0 and 1.0 $\mathrm{kg} / \mathrm{ha}$ one day after sowing of soybean resulted in its persistence in soil for 60 and 45 days respectively at the two respective doses.

\section{References}

Adhikary, P., Shil, S. and Patra, P.S. 2014. Effect of herbicides on soil microorganisms in transplanted chilli. G.J.B.A.H.S. 3(1): 236-238.

Aggarwal, N., Singh, G., Ram, H. and Khanna, V. 2014. Effect of postemergenceapplication of imazethapyr on symbiotic activities, growth and yield of blackgram (Vigna mungo L.) cultivars and its efficacy. Indian Journal of Agronomy 59(3): 421-426.

Anonymous, 2013. Weed management in blackgram/greengram and its residual effect on succeeding mustard. Annual Report 2013-2014. All India coordinated research project on weed control, Jabalpur pp 45 .

Anonymous, 2015a. Economics Survey of India, Directorate of Economics and Statistics, Government of India.

Anonymous, 2015b. Ministry of Agriculture, Government of India.

Ansar, M., Anwar, A., Arif, M., Muhammad, N. and Zahid, A. 2010. Screening of pre and post emergence herbicides against chickpea (Cicer arietinum L.) weeds under semi rainfed conditions of Pothohar, Pakistan. Pak. J. Weed Sci. Res. 16(4): 421-430.

Arora, A. and Dubey, S.K. 2014. Persistence of Pendimethalin and Chlorimuron-p-ethyl in Soil and its Impact on Soil Microorganisms. Pesticide Research Journal 26(2): 189-192.

Arora, A. and Tomar. S.S. 2008. Persistence of pendimethalin in soil applied to different 
crops. Agric. Sci. Digest 28(4): 29 -297.

Buttar, G.S. and Grover, K. 2006. Efficacy of pendimethalin and fluchloralin against weeds in clusterbean (Cyanopsis tetragonoloba $\quad$ L.) under irrigated conditions. Res Punjab Agric Univ 43(1): 17-18.

Chaudhry, A.O., Malik, B.A. and Basir, M. 1989. Critical period of weed-crop competition in urd bean and mung bean. Pak. J. Agric. Res. 10(4): 341-345.

Chaudhry, S., Verma V.K., Singh V, Pyare, R. and Singh, A.K. 2014. Studies on efficiency of herbicides against weeds of black gram (Vigna mungo). Advance Journal of Crop Improvement 5: 40-43.

Chhodavadia, S.K. 2014. Efficacy of pre- and post- emergence herbicides for integrated weed management in summer green gram (Vigna radiata L.). (Abstract) 2nd Int. Conf. on Agric. and Hort. Sci., Hyderabad, India.

Chhodavadia, S.K., Sagarka, B.K., Gohil, B.S. and Dobariya, V.K. 2012. Herbicidal weed control in green gram. agriculture: towards a new paradigm of sustainability. pp 207-211.

Chin, D.V. and Pandey, J. 1991. Effect of pre and post-emergence herbicides on weeds and yield of blackgram (Phaseolus mungo). Indian J. Agron. 36: 276-277.

Chopra, N. and Chopra, N.K. 2005. Bioefficacy of fenoxaprop, clodinafop, metribuzin alone and in combination against weeds in wheat and their residual effect on succeeding crops. Indian J. Weed Sci 37(3 \& 4): 163-166.

Choudhary, V.K., Kumar, P.S. and Bhagawati, R. 2012. Integrated weed management in blackgram (Vigna mungo) under mid hills of Arunachal Pradesh. Indian J. Agron. 57(4): 382-385.

Cumming, J.P. Brown, P.H., Doyle, R.B. and Frost, P. 2002. Distribution of the herbicides clomazone and pendimethalin in soils, and implications for activity and persistence. Thirteenth Australian Weeds Conference pp.321-324.

Das, R., Patra, B. C., Mandal, M. K. and
Pathak, A. 2014. Integrated weed management in blackgram (Vigna mungo L.) and its effect on soil microflora under sandy loam soil of West Bengal. The Bioscan 9(4): 1593-1596.

De, G.C. and Modak, R. 1993. Integrated weed management in summer blackgram (cv. B 76) in the lateritic tract of West Bengal. Proc. Indian Soc. of Weed Sci. Int. Symp Hissar, India: 150-151.

De, G.C., Chakraborty, T., Modak, R. and Das, S. 1995. Efficiency and economics of integrated weed management in chickpea and blackgram. Indian Agriculturist 39(3): 213-217.

Deivasigamani, S. 2016. Effect of bio-efficacy and phytotoxicity of fenoxaprop-p-ethyl (whip super) groundnut (Arachis hypogaea L.). International Research Journal of Natural and Applied Sciences 3(4): 46-52.

Dhingra, K.K., Sekhon, H.S. and Tripathi, H.P. 1984. Effect of herbicides for weed control in mung bean. Indian J. Weed Sci. 16(2): 116-120.

Gill, H. S., Sandhu, K. S., Mehra, S. P. and Singh, T. 1989. Efficacy of some herbicides for control of weeds in Indian mustard. Indian Journal of Weed Science 16: 171-175.

Goud, V.V., Murade, N.B., Khakre, M.S. and Patil, A.N. 2013. Efficacy of imazethapyr and quizalofop-ethyl herbicides on growth and yield of chickpea. The Bioscan 8(3): 1015-1018.

Gowada, S.J.A., Devendra, A., Prasad, T.G., Kumar, M.U. and Gowada M.K.M. 1994. Selectivity of herbicide pendimethaline on Eleusine coracana and Cajanus cajan. Proc. Indian Natn Sci Acad B60: 577-581.

Gowda, C.L.L. and Koul, A.K. (1982). Pulses in Bangladesh. Bangladesh Agric. Res. Inst. Joydebpur, Gazipur, Dhaka and FAO, Rome. Pp 431.

Gupta, O.P. 2013. Modern Weed Management, weed-crop competition, Agrobios, third revised edition, pp 21-22.

Hanson, B.D. and Thill, D.C. 2001. Effects of 
Imazethapyr and Pendimethalin on Lentil (Lens culinaris), Pea (Pisum sativum), and a Subsequent Winter Wheat (Triticum aestivum) Crop. Weed Technology 15: 190-194.

Jain, N.K. and Jain, S.C. 1987. Impact of different weed free media on the growth and yield parameters of black gram (Vigna mungo) in semi-arid tropical conditions. Indian J. Weed Sci. 19(1\& 2): 20-24.

Jakhar, P., Yadav, S.S. and Choudhary, R. 2015. Response of weed management practices on the Productivity of urdbean (Vigna mungo L. Hepper). Journal of Applied and Natural Science 7(1): 348 352.

Kathiresan, R.M. 2002. Weed management in rice-blackgram cropping system. Indian J. Weed Sci. 34(3\&4): 220-226.

Khot, D. B., Khanpara, V.D., Munde, S.D. and Shaukat, A. 2013. Effect of herbicides on weeds and yield of black gram (Vigna mungo L.). BIOINFOLET 10(2a): 462463.

Kumar, P., Saraf, C. S., Singh, R. and Chander, S. 2000. Effect of weed management and sulphur fertilization on weeds and yield in greengram and blackgram system. Indian Journal of Weed Science 32: 2530.

Kundu, R., Bera, P.S., Brhmachari, K. and Mallick, R. 2011. Integrated weed management in summer green gram (Vigna radiata $\mathrm{L}$.) under gangetic alluvial soil of West Bengal. J. Botan. Soc. Bengal 65(1): 35-43.

Mahakavi, T., Bakiyaraj, R., Baskaran, L., Rashid, N. and Ganesh, K. S. 2014. Effect of herbicide (Quizalofop-p-ethyl) on growth, photosynthetic pigments, enzymes and yield responses of blackgram (Vigna mungo L.). International Letters of Natural Sciences 9: 58-65.

Meena, D.S., Ram, B., Jadon, C. and Tetarwal, J.P. 2011. Efficacy of imazethapyr on weed management in soybean. Indian Journal of Weed Science 43(3\&4): 69-
171.

Mukhopadhyay, S., Bhattacharyya, A. and Das, A. 2012. Fate and persistence of herbicide quizalofop-p-tefuryl on black gram. Journal of Crop and Weed 8(1): 190-192.

Mukthopadhyay, S.K. 1992. Emerging problems and advances in weed management, Proc. Indian Sci. Congress, 79th Session, Calcutta, India: 1-16.

Mundra, S. L. and Maliwal, P. L. 2012. Influence of quizalofop-ethyl on narrow-

leaved weeds in blackgram and its residual effect on succeeding crops. Indian Journal of Weed Science 44(4): 231-234.

Naidu, K.R.K., Ramana, A.V. and De, B. 2012. Bio-efficacy and economics of herbicides against weeds of black gram (Vigna mungo L.) grown in ice-fallow. Journal of Crop and Weed 8(1): 133-136.

Nandan, B., Shrama, B.C., Kumar, A. and Sharma, V. 2011. Efficacy of pre and post emergence herbicides on weed flora of urd bean under rainfed subtropical Shiwalik foottills of Jammu and Kashmir.

Indian Journal of Weed Science 43(3\&4): 172-174.

Nirala, H., Choubey, N.K. and Bhoi, S. 2012. Performance of post-emergence herbicides and hand weedings with respect to their effects on weed dynamics and yields of blackgram (Vigna mungo L.). Int. J. Agricult. Stat. Sci. 8(2): 679689.

Ram, H., Singh, G., Aggarwal, N., Buttar, G.S. and Singh, O. 2013. Standardization of Rate and Time of Application of Imazethapyr Weedicide in Soybean. Indian Journal of Plant Protection 41(1): 33-37.

Rana, V.N.S., Singh, R. and Tomar, S. S. 2008. Effect of weed interference on weeds and productivity of blackgram (Phaseolus mungo). Indian J. Weed Sci. $\quad 40(1 \& 2)$ : 65-67.

Rao, A. S., Rao, G. S. and Ratnam, M. 2010. Bio-efficacy of sand mix application of pre-emergence herbicides alone and in sequence with imazethapyr on weed 
control in relay crop of black gram. Pak. J. Weed Sci. Res. 16 (3): 279-285.

Rao, A.S. 2008. Effect of time and dose of postemergence herbicides on Echinochloa colona (L.) in blackgram grown as relay crop. Indian J. Weed Sci. 40(3\&4):165- 168.

Rao, A.S. 2011. Bio-efficacy of quizalofop ethyl on Echinochloa colona control in rice fallow blackgram. The Andhra Agric. J., 58(2). (Abstract).

Rao, A.S. and Rao, R.S.N. 2003. Bioefficicacy of clodinafop propargyl on Echinochloa spp. in black gram. Ind.J. Weed Sci. 35: 251-252.

Rathi, J.P.S., Tewari, A.N. and Kumar, M. 2004. Integrated weed management in blackgram (Vigna mungo L.). Indian J. Weed Sci. 36(3\&4): 218- 220.

Reddy, M.D., Reddy, C.N. and Devi, M.P. 2000. Effect of herbicides on weed growth and crop performance in riceblackgram cropping system. Indian $J$. Weed Sci. 32(3/4): 169-172.

Saha, A., Ahammed Shabeer T.P., Banerjee, K., Hingmire, S., Bhaduri, D., Jain, N.K. and Utture, S. 2015. Simultaneous analysis of herbicide pendimethalin,

oxyfluorfen, imazethapyr and quizalofopp-ethyl by LC-MS/MS and safety evaluation of their harvest time residues in peanut (Arachis hypogaea L.). Food Sci Technol 52(7): 4001-4014.

Sahay, G., Sharma, B.K., Gupta, H.S., Pathak, K.A. And Prasad, M.S. 1999. Biotic stresses of pulses in North Eastern Hill region of India. Indian J. Hill Fmg 12(1/2): 8-16.

Samant, T.K. and Mishra, K.N. 2014. Efficacy of post-emergence herbicide quizalofopethyl for controlling grassy weeds in groundnut. Indian J. Agric. Res 48(6): 488-492.

Shaikh, A.R., Lokhande, R.H., Bhosale, R.H., Giri, A.N. and Shinde, G.G. 2002. Weed management in blackgram (Vigna mungo L.). Indian Journal of Agronomy 47(2): 231-233.

Sharma, J. nd Nayital S.C. 1991. Crop weed competition in maize (Zea mays) plus blackgram (Phaseolus mungo) intercropping system. Indian J. Agron. 36: 64-67.

Sheoran, P., Singh, S., Sardana, V. and Bawa, S.S. 2008. Studies on critical period of crop-weed competition in green gram in Kandi region of Punjab. Indian $J$. Dryland Agric. Res. and Dev. 23(1): 1922.

Shrivas, A., Kaleem, M., Singh, S. and Chandrawanshi, S.K. 2013. Bio-efficacy of imazethapyr at various doses in kharif groundnut (Arachis hypogaea L.) on sandy loam soil. Legume Research, 36(4): 368-370.

Singh, A.K. 1993. Performance of mungbean and urdbean varities under varying seed rate during spring/summer. Thesis, M.Sc., G.B.P.U.A\&T., Pantnagar, pp146.

Singh, A.K. and Vaishya, R.D. 1998. Weed management studies in chickpea (Cicer arietinum) under varying levels of phosphorus. Ph.D. Thesis submitted to the DUAT, Kumarganj. Faizabad.

Singh, G. 1985. Final Tech. Report, All India Coord. Res. Prog. Weed Control, G. B. Pant Univ. of Agric. and Tech. Pantnagar, India: 24-26.

Singh, G. 2011. Weed Management in summer and kharif season blackgram [Vigna mungo (L.) Hepper]. Indian J. Weed Sci. 43(1\&2): 77-80.

Singh, M.K., Thakur, R., Verma, U.N., Pal, S.K. and Pasupalak, S. 1998. Productivity and nutrient balance of maize (Zea mays) + black gram (Phaseolus mungo) intercropping as affected by fertilizer and plant density management of black gram. Indian J. Agron. 43(3): 495-500.

Singh, R., Chandel, A.S. and Singh, R. 1991. Economics of weed control methods in urd bean (Vigna mungo (L.) Hepper). Haryana J. Agron. 7(2): 169- 170.

Singh, R., Chandel, A.S. and Singh, R. 1991. Economics of weed control methods in urd bean (Vigna mungo (L.) Hepper). Haryana J. Agron. 7(2): 169-170.

Singh, R.P., Singh, D. and Ramesh, K. 2014. 
Effect of pre and post-emergence herbicides on growth and yield of black gram (Vigna mungo L.). Green Farming 5(5): 876-879.

Singh, V.K. and Singh, R.P. 1990. Chemical weed control in blackgram (Vigna mungo L.). Indian J. Weed Sci. 20(4): 81-82.

Singh, V.P., Singh, S.P., Kumar, A., Tripathi, N. and Nainwal, R.C. 2010. Efficacy of Haloxyfop, a post-emergence herbicide on weeds and yield of soybean. Indian Journal of Weed Science 42(1\&2): 83-86.

Soltani, N., Shropshire, C. and Sikkema, P.H. 2015. Pendimethalin Residues from Weed Management in Dry Bean Can Cause Injury in Autumn Seeded Winter Wheat. Agricultural Sciences 6: 159-163.

Soltania, N., Chris L.G., Clarence J.S., Christy, S. and Peter, H.S. 2008. Response of white bean (Phaseolus vulgaris) to imazethapyr. Crop Protection 27: 672677.

Sondhia, S., Khankhane, P.J., Singh, P.K. and Sharma, A.R. 2015. Determination of imazethapyr residues in soil and grains after its application to soybeans. $J$. Pestic. Sci. 40(3): 106-110.

Suryakant, Oahia, O.R. and Hooda, I.S. 1989. Effect of weed control methods on growth, yield and yield attributes of urd bean. Indian J. Haryana 5(1): 18-23.

Tamang, D., Nath, R. and Sengupta, K. 2015. Effect of Herbicide Application on Weed Management in Green Gram [Vigna radiata (L.) Wilczek]. Adv Crop Sci Tech
3(2): 163-166.

Tomar, A.S. 2011. Evaluation of quizalofop pethylm $4.41 \%$ EC against grassy weeds in black gram (Vigna mungo L.). Journal of Crop and Weed 7(1): 140-141.

Veeraputhiran, R. and Chinnusamy, C. 2008. Performance of time and dose of post emergence herbicide application on relay cropped black gram. Indian Journal of Weed Science 40(3\&4): 173-175.

Velayudham, K. 2007. Economics of practicing integrated weed management in blackgram. Madras Agric. J. 94(1/6): 5560.

Venkateswarulu, V., Rao, V.V., Rao, A.S. and Rao, D.S.K. 1988. Effect of methods of weed control and phosphorus levels in blackgram (Vigna mungo). Indian $J$. Weed Sci. 20(1): 74-77.

Vivek, N.S., Singh, R.R. and Tomar S.S. 2008. Effect of weed interference on weeds and productivity of blackgram (Phaseolus mugo). Indian Journal of Weed Science 40(1\&2): 65-67.

Yadav, R.P., Yadav, K.S. and Srivastava, U.K. 1997. Integrated weed management in black gram (Phaseolus mungo). Indian J. Agron. 42(1):124-126.

Yadav, V.K. and Singh, S.P. 2005. Losses due to weeds and response to pendimethalin and fluchloralin in varieties of summer sown Vigna radiate. Ann Pl Protec Sci 13(2): 454-457.

\section{How to cite this article:}

Sooraj Chandra Pankaj and Pradeep Kumar Dewangan. 2017. A Critical Review on Weed Management in Black Gram (Vigna mungo L.) and Residual Effect of Herbicides on Succeeding Mustard (Brasica juncea L.) Crop. Int.J.Curr.Microbiol.App.Sci. 6(11): 865-881. doi: https://doi.org/10.20546/ijcmas.2017.611.101 